Saudi Journal of Humanities and Social Sciences

Abbreviated Key Title: Saudi J Humanities Soc Sci

ISSN 2415-6256 (Print) | ISSN 2415-6248 (Online)

Scholars Middle East Publishers, Dubai, United Arab Emirates

Journal homepage: https://saudijournals.com

Review Article

\title{
Legal Basis for the Implementation of Work from Home Amid The COVID-19 Pandemic in Indonesia
}

\author{
Henry Aspan ${ }^{1 *}$ \\ ${ }^{1}$ Universitas Pembangunan Panca Budi, Medan, Indonesia
}

DOI: $10.36348 /$ sjhss.2021.v06i04.002

| Received: 28.02.2021 | Accepted: 01.04.2021 | Published: 06.04.2021

*Corresponding author: Henry Aspan

\section{Abstract}

The COVID-19 pandemic has spread to almost all countries in the world, including Indonesia. Particularly in Indonesia, the COVID-19 pandemic has several impacts, not only on public health but also on lifestyles as a result of various policies from the authorities that apply to handling COVID-19, such as in the fields of economy, social, politics, education, to psychological. Some suggestions that are needed regarding the legal basis for implementing Work From Home (WFH) are as follows: (a) There is still a need for a new integrated policy between the central government and the regions that specifically regulates Work From Home (WFH); (b) The importance of regulating the rights and obligations of parties such as workers, employers, and related institutions in regulating Work From Home (WFH); (c) The importance of involving parties such as workers, employers, and related institutions in regulating Work From Home (WFH) so that the regulations are made more targeted.

Keywords: Coronavirus, Work from Home, Social Distance, Regulation, Rights, Obligation.

Copyright (C) 2021 The Author(s): This is an open-access article distributed under the terms of the Creative Commons Attribution 4.0 International License (CC BY-NC 4.0) which permits unrestricted use, distribution, and reproduction in any medium for non-commercial use provided the original author and source are credited.

\section{INTRODUCTION}

A COVID-19 pandemic is an event that the spread of Coronavirus disease 2019, abbreviated as COVID-19 throughout the world. This disease is caused by a new type of coronavirus named SARS-CoV-2. The COVID-19 outbreak was first detected in Wuhan City, Hubei Province, China on 1 December 2019, and was declared a pandemic by the World Health Organization (WHO) on 11 March 2020 [1].

The COVID-19 pandemic has spread to almost all countries in the world, including Indonesia. Particularly in Indonesia, the COVID-19 pandemic has several impacts, not only on public health but also on lifestyles as a result of various policies from the authorities that apply to handling COVID-19, such as in the fields of economy, social, politics, education, to psychological.

The most striking impact is the social and economic life in Indonesia. The government issued a policy to limit the space for the transmission of

\footnotetext{
1"Pademi Covid-19".

https://id.wikipedia.org/wiki/Pandemi_COVID-19. Diakses Tanggal 19 September 2020.
}

COVID-19 in various ways, including carrying out large-scale social restrictions. Large-scale social restrictions are restrictions on the movement of the community to carry out their activities outside the home for the sake of social distancing or physical distancing.

Current conditions, the government and society rely more on digital technology to continue living social and economic life. One of them is the work from home (WFH) policy. Therefore, the author chooses a topic for the thesis with the legal basis of implementing work from home amid the Covid-19 outbreak in Indonesia. Therefore, the research questions are as follows.

RQ1: What is the legal basis for implementing Work From Home (WFH) amid the COVID-19 outbreak in Indonesia?

RQ2: How is the implementation of Work From Home (WFH) during the COVID-19 outbreak in Indonesia?

\section{LITERATURE REVIEW}

The legal basis for implementing work from home (WFH) amid the Covid-19 outbreak in Indonesia

Work From Home (WFH) is a concept where employees do all office work at home. Work From Home (WFH) also has positive and negative impacts. 
The positive impact is that it can provide time flexibility for workers so that the worker's life balance is better and for companies is to reduce the company's operational costs. Also, the negative impact is decreased productivity during Work From Home (WFH). The causes of decreased productivity during Work From Home (WFH) are lack of supervision of workers resulting in loss of work motivation, many distractors that make workers lose focus on work, frequent miscommunication and data security problems.

The legal basis for implementing Work From Home (WFH) can be related to the provisions, namely. 1) Article 86 paragraph (1) the letter of the law Number 13 the Year 2003 concerning Manpower. 2) Government Regulation Number 78 of 2015 concerning Wages. 3) Circular from the DKI Jakarta Province Manpower, Transmigration and Energy Office Number 14 / SE / 2020 of 2020 concerning the Appeal to Work from Home. 4) Circular of the Minister of Manpower Number M / 3 / HK.04 / III / 2020 of 2020 concerning Protection of Workers / Laborers and Business Continuity in the Context of Prevention and Management of the COVID-19 epidemic. 5) Minister of Manpower Circular Number M / 3 / HK.04 / III / 2020 of 2020 concerning Protection of Workers / Laborers and Business Continuity in the Context of Prevention and Control of the COVID-19 epidemic. 6) Circular of the Minister of Manpower Number: SE-05 / M / BW / 1998 concerning Wages for Workers who Are Sent Home Not in the Direction of Termination of Employment. 7) Circular of the Minister of Manpower Number: SE-907 / MEN / PHI-PPHI / X / 2004 concerning Prevention. 8) Circular of the Minister of Administrative Reform and Bureaucratic Reform Number 58 of 2020 concerning the Work System of State Civil Servants in the New Normal Order.

\section{Implementation work from home (WFH) amid the covid-19 outbreak in Indonesia}

The legal basis for implementing Work From Home (WFH) can be linked to the provisions of Article 86 paragraph (1) letter a of Law Number 13 of 2003 concerning Manpower, where every worker or laborer has the right to obtain protection for occupational safety and health [2].

The term "to house workers" or "workers who are sent home" is not known and is not regulated in the provisions of Law Number 13 the Year 2003 concerning Manpower. Even so, in practice and some cases, there are workers who are "laid off" (but not laid off) by the company for various reasons, such as because the company cannot carry out production, the

\footnotetext{
${ }^{2}$ https://www.law-justice.co/artikel/83389/pelaksanaanwork-from-home-di-indonesia-ini-dasar-hukumnya/, diakses tanggal 19 September 2020
}

company is restructuring its business. A particular crisis is hitting the company [3].

Employees who work from home (WFH) are still given full wages or wage deductions if it has been agreed upon by the company and the worker. in the form of money as compensation from the entrepreneur or employer to the worker / laborer which is determined and paid according to a work agreement, agreement, or statutory regulation, including allowances for the worker / laborer and their family for a job and / or service that has been or will be done [4].

Wage is an acceptance as a reward from giving work to a working recipient for a job or service. It has been and or will be performed, functions as a guarantee for the continuity of life worthy of humanity and production, expressed or valued in the form of money determined according to a job based on an employment agreement. (Nasution, 1994).

In terms of cutting workers' wages, it has been regulated in Government Regulation Number 78 of 2015 concerning Wages with certain conditions. In the event of a deduction of employee wages, because the company is losing money due to Pademi COVID-19, the wage deduction is not based on law. It can lead to industrial relations disputes, namely rights disputes.

The Department of Manpower, Transmigration and Energy of the Special Capital Region of Jakarta Province itself has issued a Circular of the DKI Jakarta Province Manpower, Transmigration and Energy Office Number 14 / SE / 2020 of 2020 concerning the Appeal to Work from Home which follows up on the Governor's Instruction DKI Jakarta Province Number 16 the Year 2020 concerning Increased Vigilance Against the Risk of Corona Virus Disease (COVID-19) Transmission. The purposes and objectives of this Circular Letter are: (1) As a reference for work unit leaders and/or Civil Servants in making reports on the whereabouts of Civil Servants. (2) As a guideline for Civil Service Officers in making decisions on activities to travel outside the region and/or go home for Civil Servants within the work unit of the State Personnel Agency. (3) As a reference for work unit leaders in imposing disciplinary penalties for civil servants who violate them. (4) As an effort to prevent and minimize the spread of the coronavirus (COVID-19).

\footnotetext{
${ }^{3}$ https://gajimu.com/tips-karir/kondisi-kerja-dankehidupan-di-tengah-pandemi-covid-19-indonesia/faqketenagakerjaan-dan-covid-19/faq-bekerja-di-tengahpandemi-covid-19/faq-bekerja-di-tengah-pandemicorona/\#hukum-yang-mengatur-perihal--merumahkanpekerja--

${ }^{4}$ Pasal 1 angka 30 Undang-Undang Nomor 13 Tahun 2003 tentang Ketenagakerjaan
} 
Companies can classify preventive measures into three categories: (1) Companies can temporarily suspend all of their business activities. (2) The company may temporarily reduce some of its business activities (part of its employees, time and operational facilities). (3) Companies are unable to stop their business activities, bearing in mind the direct interests related to services.

On 17 March 2020 a Circular of the Minister of Manpower Number M / 3 / HK.04 / III / 2020 of 2020 concerning Protection of Workers / Laborers and Business Continuity in the Context of Prevention and Control of the COVID-19 epidemic has been issued. In connection with the increasing spread of the COVID-19 epidemic in several regions of Indonesia and paying attention to the official statement of the World Health Organization (WHO) which declares COVID-19 a global pandemic. One of the things regulated in SE Menaker $3 / 2020$ is the implementation of (1) For workers/labourers who are categorized as People Under Monitoring for COVID-19. It based on a doctor's statement so that they cannot come to work for a maximum of 14 days or according to Ministry standards Health, and then the wages are paid in full. (2) For workers/labourers who are categorized as suspected cases of COVID-19 and quarantined/isolated according to a doctor's statement, their wages are paid in full during the quarantine/isolation period. (3) For workers/labourers who do not come to work because of being sick with COVID-19 and proven by a doctor's statement, their wages are paid according to the statutory regulations. (4) For companies that limit their business activities due to government policies in their respective regions for the prevention and control of COVID-19, causing some or all of their workers/labourers not to work, taking into account business continuity, changes in the amount and method of payment of workers' wages. / labor is carried out according to the agreement between the entrepreneur and the worker / laborer. By considering the continuity of business, changes the amount and method of payment of workers' wages are carried out following the agreement between the entrepreneur and the worker.

Following are 2 (two) Circular of the Minister of Manpower relating to the COVID-19 pandemic, among others.

1. Circular of the Minister of Manpower Number: SE-05 / M / BW / 1998 concerning Wages for Workers who are Sent Home Not in the Direction of Termination of Employment. What regulates employers to continue to pay wages in full, namely in the form of basic wages and fixed allowances while the workers are laid off, unless otherwise stipulated in the Work Agreement, Company Regulation or Collective Bargaining Agreement. If the employer does not pay the workers 'wages in full, it must be negotiated with the workers' union and or workers regarding the number of wages for being laid off.

In the Circular of the Minister of Manpower Number: SE-05 / M / BW / 1998, it is explained that many companies experience difficulties. As an effort to save the company, actions are taken to temporarily house workers, with the following wages: (a) Employers continue to pay wages in full, namely in the form of basic wages and fixed allowances as long as workers are dismissed unless otherwise stipulated in the work agreement, company regulations. , or a collective labour agreement. (b) If the employer is to pay the workers' wages not in full, it is necessary to negotiate with the workers' and/or workers' wages regarding the number of wages during their stay and the length of time they are sent home. (c) If the negotiation through the service of an intermediary employee turns out that no agreement is reached, a letter of recommendation is immediately issued. If this recommendation is rejected by one or both of the disputing parties, then the matter is to be immediately transferred to P4 Regional, or P4 Central, for mass layoffs.

2. Circular of the Minister of Manpower Number: SE-907 / MEN / PHI-PPHI / X / 2004 concerning Prevention. What regulates that if a company experiences difficulties that can affect employment, termination of employment must be a last resort, after various efforts have been made, namely: reducing wages and upper-level workers' facilities, reducing shifts, reducing working hours, reducing working days, leaving or laying off workers. Workers/labourers take turns for the time being.

In SE-907 / MEN / PHI-PPHI / X / 2004 the YEAR 2004 concerning carrying out the above Final Efforts to avoid layoffs, it is said that "The selection of alternatives to matters as mentioned above needs to be discussed first with the trade union / union workers or with workers '/ laborers' representatives in the event that there is no trade / labor union in that company to obtain a biparte agreement so that the possibility of termination of employment can be prevented."

This case means that the final effort to be made to avoid layoffs between Entrepreneurs and Workers / Laborers needs to be discussed in advance between the trade/labour union or with workers/labour representatives in the case of the company, if there is no trade/labour union then it must first get an agreement on a bipartite basis (Entrepreneur \& Labor / Laborer).

As for government agencies, the Work From Home (WFH) policy has initially been formulated in the Circular of the Minister of State Apparatus Empowerment and Bureaucratic Reform Number 19 of 2020 concerning Adjustments to the Work System of State Civil Apparatus in Efforts to Prevent the Spread 
of COVID-19 within Government Agencies and its amendments.

In addition, there is a Circular of the Minister of Administrative Reform and Bureaucratic Reform Number 45 of 2020 concerning Adjustments of Work Systems for State Civil Apparatus in Government Agencies in Areas with Large-Scale Social Restrictions.

However, both circulations have been revoked with the Circular of the Minister of Administrative Reform and Bureaucratic Reform Number 58 of 2020 concerning the Work System for State Civil Servants in the New Normal Order ("SE MENPANRB 58/2020"). SE MENPANRB 58/2020 contains a working system for employees of the State Civil Service ("ASN") in the administration of government within ministries/agencies/regions to adapt to the new productive and safe COVID-19 normal order. ASN employees are required to come to work, but adjustments to the work system need to be made by implementing health protocols in their daily activities.

The work system adjustment is carried out through the flexibility of work location arrangements, namely the implementation of official duties in the office (Work From Office / "WFO"); and/or the implementation of official duties at home/residence (Work From Home / "WFH). ASN employees carry out Work from Office (WFO) under the provisions of laws and regulations in the field of employment.

Meanwhile, ASN employees who work from home (WFH) carry out official duties at the home/residence where they are assigned/assigned to government agencies, which are still implemented under the provisions of laws and regulations in the field of employment. Regarding the flexibility of the work location, staffing officers: (1) Manage an accountable and selective work system for the work unit environment that can perform Work From Office (WFO) and/or Work From Home (WFH) with due regard to the conditions of the spread of COVID-19 in respective areas. (2) Determine ASN employees who can carry out Work From Home (WFH), with the following considerations: type of employee job, results of employee performance appraisals, employee competence in operating systems and information technology, employee discipline reports, health conditions/employee comorbidity factors, residence employees are in the PSBB area, the health condition of the employee's family (Status Insider Monitoring / Supervision / confirmed positive for COVID-19), history of domestic/foreign travel in the last 14 calendar days, history of interactions with sufferers confirmed positive for COVID-19 within 14 days last calendar and the effectiveness of the implementation of tasks and services of organizational units.
Meanwhile, the personnel advisory officials located in the Large-Scale Social Restrictions urge to: assign ASN employees to carry out Work From Home (WFH) in full while still paying attention to performance targets and work targets and regulating ASN employees whose duties and functions are strategic according to the Regulation The Minister of Health Number 9 of 2020 concerning Guidelines for Large-Scale Social Restrictions in the Context of Accelerating the Handling of Corona Virus Disease 2019 (COVID-19), to carry out Work From Office (WFO) with a minimum number of employees while still prioritizing health protocols.

Public services are all forms of services, both in the form of public goods and public services, which in principle are the responsibility of and implemented by Government Agencies at the Central, Regional and in the environment of State-Owned Enterprises or Regionally-Owned Enterprises, in the framework of fulfilling efforts. The community needs as well as in the framework of implementing the provisions of laws and regulations. To ensure the smooth operation of public services, Ministries / Institutions / Regions must: (1) Simplify business processes and standard operating service procedures by utilizing information and communication technology. (2) Using information media to deliver new service standards through publication media. (3) Opening online communication media as a forum for consultation and complaints. (4) Ensuring that the output of service products carried out online and offline remains following the predetermined standards. (5) Paying attention to the safe distance (physical distancing), health and safety of employees who provide direct offline services under the health protocol stipulated by the Minister of Health.

The government on 11 April 2020 issued a policy by releasing the Pre-Employment Card Program. Implementation of the 2020 Pre-Work Card is the implementation of Presidential Instruction (Inpres) Number 4 of 2020 concerning Activity Re-focusing, Budget Reallocation, and Procurement of Goods and Services for the Acceleration of Handling Coronavirus Disease 2019 (Covid-19).

\section{CONCLUSION \& SUGGESTIONS}

The legal basis for implementing Work From Home (WFH) can be linked to the following provisions: (a) Article 86 paragraph (1) the letter of the law Number 13 the Year 2003 concerning Manpower ("Manpower Law"). (b) Government Regulation Number 78 of 2015 concerning Wages. (c) DKI Jakarta Provincial Manpower, Transmigration and Energy Agency Circular Number 14 / SE / 2020 of 2020 concerning Work From Home Appeals. (d) Circular of the Minister of Manpower Number M / 3 / HK.04 / III / 2020 of 2020 concerning Protection of Workers / Laborers and Business Continuity in the Context of Prevention and Management of the COVID-19 
epidemic. (e) Circular of the Minister of Manpower Number M / 3 / HK.04 / III / 2020 of 2020 concerning Protection of Workers / Laborers and Business Continuity in the Context of Prevention and Management of the COVID-19 epidemic. (f) Circular of the Minister of Manpower Number: SE-05 / M / BW / 1998 concerning Wages for Workers who are Sent Home Not in the Direction of Termination of Employment. (g) Circular of the Minister of Manpower Number: SE-907 / MEN / PHI-PPHI / X / 2004 concerning Prevention. (h) Circular of the Minister of Administrative Reform and Bureaucratic Reform Number 58 of 2020 concerning the Work System of State Civil Servants in the New Normal Order.

The legal basis for the implementation of Work From Home (WFH) can be linked to the provisions of Article 86 paragraph (1) the letter of the law Number 13 of 2003 concerning Manpower ("Manpower Law"), where every worker or labourer has the right to obtain protection for safety and occupational health.

The Department of Manpower, Transmigration and Energy of the Special Capital Region of Jakarta Province itself has issued a Circular of the DKI Jakarta Provincial Manpower, Transmigration and Energy Office Number 14 / SE / 2020 of 2020 concerning the Appeal to Work at Home ("SE Disnakertrans and Energi DKI Jakarta 14/2020 ") which follows up on the Instruction of the Governor of DKI Jakarta Province Number 16 of 2020 concerning Increased Alertness Against the Risk of Corona Virus Disease (COVID-19) Infection.

Here are 2 (two) Circular of the Minister of Manpower relating to the Pademi COVID-19, including the Circular of the Minister of Manpower No: SE-05 / M / BW / 1998 concerning Wages for Workers who are Sent Home Not in the Direction of Termination of Employment and Circular Minister of Manpower No: SE-907 / MEN / PHI-PPHI / X / 2004 concerning Prevention and Circular of the Minister of State Apparatus Empowerment and Bureaucratic Reform Number 58 of 2020 concerning the Work System of State Civil Servants in the New Normal Order ("SE MENPANRB 58/2020")

\section{SUGGESTIONS}

1. Based on the description in this paper, some suggestions are needed regarding the legal basis for conducting Work From Home (WFH), namely as follows: (a) There is still a need for a new integrated policy between central and regional that specifically regulates Work From Home (WFH). ); (b) The importance of regulating the rights and obligations of parties such as workers, employers, and related institutions in regulating Work From Home (WFH); (c) The importance of involving parties such as workers, employers, and related institutions in regulating Work From Home (WFH) so that the regulations are made more targeted.

2. Regarding the implementation of Work From Home (WFH), the suggestions that can be given are as follows: (a) There is a need for increased cooperation between the government and the private sector in implementing Work From Home (WFH) activities during this pandemic period, in order to accelerate the pandemic handling process ; (b) There is still need for supervision from related agencies regarding the implementation of Work From Home (WFH) activities, especially regarding the importance of carrying out Work From Home (WFH) activities; things that need to be considered by the parties in Work From Home (WFH); as well as the rights and obligations of each party during Work From Home (WFH) so that no rights are violated during Work From Home (WFH).

\section{REFERENCES}

\section{Rules and Regulations}

1. Undang-Undang Nomor 13 Tahun 2003 tentang Ketenagakerjaan ("UU Ketenagakerjaan").

2. Peraturan Pemerintah Nomor 78 Tahun 2015 tentang Pengupahan.

3. Surat Edaran Dinas Tenaga Kerja, Transmigrasi dan Energi Provinsi DKI Jakarta Nomor 14/SE/2020 Tahun 2020 tentang Himbauan Bekerja di Rumah (Work From Home).

4. Surat Edaran Menteri Ketenagakerjaan Nomor M/3/HK.04/III/2020 Tahun 2020 tentang Perlindungan Pekerja/Buruh dan Kelangsungan Usaha dalam Rangka Pencegahan dan Penanggulangan pademi COVID-19.

5. Surat Edaran Menteri Ketenagakerjaan Nomor M/3/HK.04/III/2020 Tahun 2020 tentang Perlindungan Pekerja/Buruh dan Kelangsungan Usaha dalam Rangka Pencegahan dan Penanggulangan pademi COVID-19.

6. Surat Edaran Menteri Tenaga Kerja Nomor : SE05/M/BW/1998 tentang Upah Pekerja yang Dirumahkan Bukan Kearah Pemutusan Hubungan Kerja.

7. Surat Edaran Menteri Tenaga Kerja Nomor : SE907/MEN/PHI-PPHI/X/2004 tentang Pencegahan.

8. Surat Edaran Menteri Pendayagunaan Aparatur Negara dan Reformasi Birokrasi Nomor 58 Tahun 2020 tentang Sistem Kerja Pegawai Aparatur Sipil Negara dalam Tatanan Normal Baru.

9. Surat Edaran Menteri Pendayagunaan Aparatur Negara dan Reformasi Birokrasi Nomor 19 Tahun 2020 tentang Penyesuaian Sistem Kerja Aparatur Sipil Negara dalam Upaya Pencegahan Penyebaran COVID-19 di Lingkungan Instansi Pemeritah dan perubahannya.

10. Surat Edaran Menteri Pendayagunaan Aparatur Negara dan Reformasi Birokrasi Nomor 45 Tahun 2020 tentang Penyesuaian Sistem Kerja bagi 
Aparatur Sipil Negara pada Instansi Pemerintah yang Berada di Wilayah dengan Penetapan Pembatasan Sosial Berskala Besar.

\section{Book}

Nasution, Mulia, 1994, Manajemen Personalia, Djambatan, Jakarta

\section{Website}

https://id.wikipedia.org/wiki/Pandemi_COVID-19.

Diakses tanggal 19 September 2020. https://www.law-justice.co/artikel/83389/pelaksanaanwork-from-home-di-indonesia-ini-dasar-hukumnya/, diakses tanggal 19 September 2020

https://gajimu.com/tips-karir/kondisi-kerja-dankehidupan-di-tengah-pandemi-covid-19-indonesia/faqketenagakerjaan-dan-covid-19/faq-bekerja-di-tengahpandemi-covid-19/faq-bekerja-di-tengah-pandemicorona/\#hukum-yang-mengatur-perihal--merumahkanpekerja--

https://id.wikipedia.org/wiki/Pelayanan_publik. Diakses tanggal 19 Septmeber 2020. 